\title{
EMERGENCE OF WEEDS AS AFFECTED BY VERTICAL SEED DISTRIBUTION IN ARABLE SOILS
}

\author{
T.K. JAMES, A. RAHMAN, T. WEBSTER and J. WALLER \\ AgResearch, Ruakura Research Centre, Private Bag 3123, Hamilton \\ Corresponding author: trevor.james@agresearch.co.nz
}

\begin{abstract}
A glasshouse study examined weed seedling emergence in soils collected from 20 sites. Soil was placed in open topped columns of differing heights and the number of seedlings that emerged were counted. A total of 77 different weed species emerged but most were in small numbers. Four summer broadleaf weeds, black nightshade (Solanum nigrum), fathen (Chenopodium album), spurrey (Spergula arvensis) and willow weed (Polygonum persicaria), showed little restriction and emerged freely from depths up to $50 \mathrm{~mm}$. Of the grasses, summer grass (Digitaria sanguinalis) and annual poa (Poa annua) were clearly constrained at depths greater than $20 \mathrm{~mm}$ while smooth witchgrass (Panicum dichotomiflorum) was not. Of the other broadleaf weeds, waxweed (Hydrocotyle sp.) and Lotus sp. were constrained at depths greater than $30 \mathrm{~mm}$ while two small-seeded species, cudweed (Gnaphalium sp.) and toad rush (Juncus bufonius) did not emerge from depths greater than $10 \mathrm{~mm}$.

Keywords: Seed bank, weed seeds, weed emergence, seed depth, arable weeds.
\end{abstract}

\section{INTRODUCTION}

Most species of annual weeds depend on prolific seed production and a persistent seedbank in the soil for long term survival. Weed seeds shed by the maturing plants either remain on the soil surface or are incorporated into the soil by natural or artificial means. The estimates of viable seeds in the soil seedbank provide a good indication of future weed infestations (Cardina \& Sparrow 1996; Forcella 1993). However, the fate of weed seeds in the soil is determined by both internal physiological conditions and the environmental conditions encountered in the soils (Murdoch \& Ellis 1992). These influences combined with natural seed loss and mortality (James et al. 1998) result in only about 3 to $6 \%$ of the seedbank establishing as seedlings each year (Wilson \& Lawson 1992).

The distribution of weed seeds in the seedbank in relation to soil depth has a major influence on seedling recruitment. Factors such as weed species, soil type, tillage, seeding practice and soil-applied herbicides have a strong bearing on the depth of seedling recruitment (Buhler \& Mester 1991; du Croix Sissons et al. 2000). Many recruitment experiments have been conducted by placing weed seeds at specific depths in the soil (e.g. Grundy et al. 1999), but only a few studies have been conducted to determine recruitment depth from natural weed seedbanks (Buhler \& Mester 1991; Chancellor 1964; du Croix Sissons et al. 2000) and these have shown the direct influence of depth and the tillage system. The objective of the present study was to determine the effect of depth on seedling emergence for several important weeds in arable soils. This information will advance the development of a robust model for predicting weed emergence based on the size of the weed seedbank in arable soils.

\section{MATERIAL AND METHODS}

During the summer of 2001/02, bulk soil samples (4 kg) were collected from 20 sites in Waikato and Bay of Plenty using a $75 \mathrm{~mm}$ diameter corer to a depth of $100 \mathrm{~mm}$. Each sample was passed through a $2 \mathrm{~mm}$ sieve and then thoroughly mixed by rolling in a

New Zealand Plant Protection 55:213-217 (2002) 
small, barrel type concrete mixer (Odjob Revolutionary Mixer) for 5 min. When thoroughly mixed, aliquots of soil were lightly packed into sections of $110 \mathrm{~mm}$ diameter PVC pipe of various lengths and open at both ends. These were then set out onto a tray $(450 \times 310 \times 60 \mathrm{~mm})$ containing wet vermiculite with a sheet of permeable weed mat separating the soil from the vermiculite. Four replicates of each of the PVC segments were set up for each soil. The pipe sections were 5, 10, 15, 20, 30 and $50 \mathrm{~mm}$ long, which when filled with soil gave columns of soil of the equivalent depth.

The soil columns were maintained in a glasshouse for about 7 weeks and the weed seedlings allowed to emerge. Moisture in the soil columns was maintained close to field capacity by keeping the vermiculite wet. Temperatures in the glasshouse ranged from $12^{\circ} \mathrm{C}$ at night to $35^{\circ} \mathrm{C}$ during the day. As soon as the seedlings could be identified they were counted and removed.

The data presented in Figure 1 for individual species are the combined seedling totals from all soils. For two typical examples, fathen (Chenopodium album) and summer grass (Digitaria sanguinalis), a Bayesian smoothing spline with $95 \%$ confidence interval for the line is presented using data from individual soils.

\section{RESULTS AND DISCUSSION}

A total of 77 different weed species emerged from the 20 soil samples, although most of these were found in small numbers and in three or less soils. No species were found common to all sites but toad rush (Juncus bufonius) was found in 19 soils. Cudweed (Gnaphalium sp.), annual poa (Poа апnиа) and summer grass were found in 17 soils, Oxalis spp. in 15 soils, black nightshade (Solanum nigrum), fathen, smooth witchgrass (Panicum dichotomiflorum) and speedwell (Veronica sp.) in 13 soils, hawksbeard (Crepis sp.) and wild portulaca (Portulaca oleracea) in 12 soils, twin cress (Coronopus didymus) in 11 soils and willow weed (Polygonum persicaria) and scarlet pimpernel (Anagallis arvensis) in 10 soils. Despite these weeds appearing in the majority of soils, some only occurred in low numbers and results are not presented here. Three other species were found in larger quantities but fewer soils and have been included in this study. They are, Lotus sp. and spurrey (Spergula arvensis), both found in eight soils and waxweed (Hydrocotyle sp.) found in two soils.

The emergence data for the 12 selected weed species are presented in Figure 1. Using
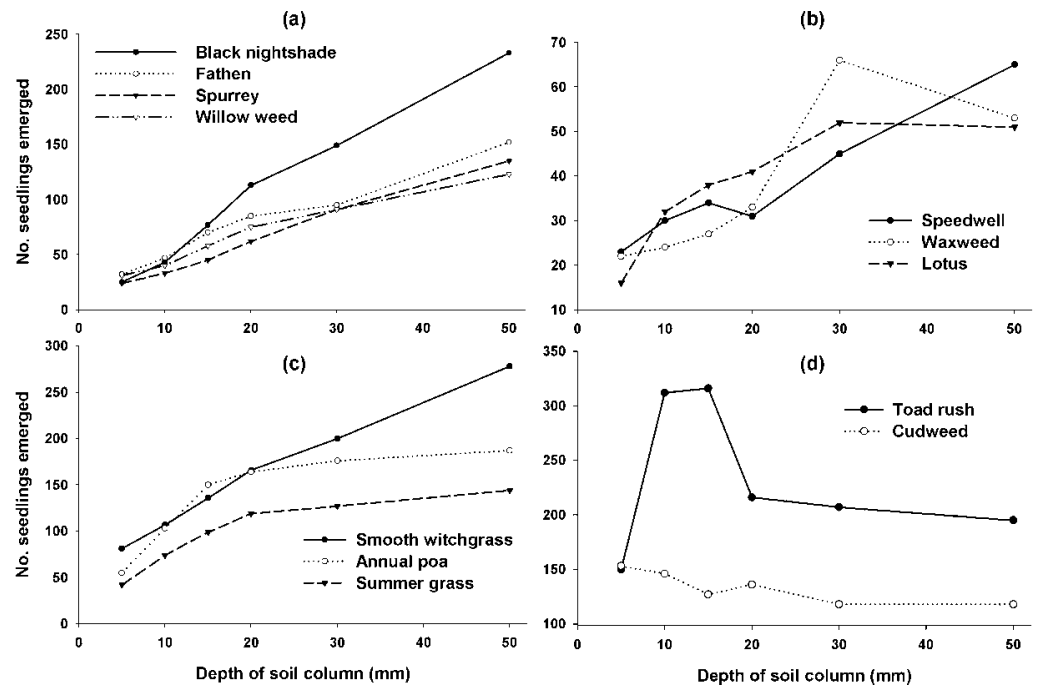

FIGURE 1: Total number of seedlings of various weed species emerging from soil columns of different depths. Data are the total number for all 20 soils. 
the method described above to study seedling emergence from different depth fractions, it is assumed that with thorough mixing the weed seeds get evenly distributed through the soil and that the only barrier to emergence is the depth at which the seed is located. If weed emergence is not constrained by depth of placement, then there should be a doubling of weed numbers with each doubling of soil column depth. If however, seedling emergence is constrained by depth of placement then there will be a levelling off of weed numbers with greater column depth as there are no contributing seedlings from the greater depths.

Four of the weed species in this study viz. black nightshade, fathen, spurrey and willow weed, germinate mostly in spring and have medium to large seed (Table 1). The emergence data for these weeds show that for each progressive soil depth, larger numbers of seedlings emerged (Fig. 1a). This indicates that they are not constrained by soil depths up to $50 \mathrm{~mm}$. To show the degree of variation in the seedling emergence, data from individual soils are presented for fathen and summer grass with a fitted spline and $95 \%$ confidence intervals (Figs 2a \& 2b). Analysis of the fathen data indicated that emergence numbers might be beginning to decline as the soil depth approaches $50 \mathrm{~mm}$ but this result was not statistically significant (Fig. 2a). This finding is in contrast to that of Chancellor (1964) who found in Britain that for fathen and willow weed the majority emerged from the top $20 \mathrm{~mm}$ and less than $2 \%$ emerged from depths greater than $40 \mathrm{~mm}$. Similarly, in a large study involving 44 fields in Canada, du Croix Sissons et al. (2000) found that for five common weeds the average depth from which they emerged ranged from $22-40 \mathrm{~mm}$ but few emerged from depths greater than $50 \mathrm{~mm}$. The most likely reason for the different behaviour in our study is the lighter, more friable nature of the New Zealand soils. The soils used in this study were all volcanic in origin and light textured, with bulk densities ranging from $0.68-0.80 \mathrm{~kg} / \mathrm{litre}$. In contrast most arable soils in Britain and Canada have bulk densities greater than $1 \mathrm{~kg} / \mathrm{litre}$.

TABLE 1: The range in seed size, measured at the largest dimension, for six large and six small seeds. Data taken from Anon. (1990).

\begin{tabular}{llll}
\hline Small seed & Size $(\mathrm{mm})$ & Large seed & Size $(\mathrm{mm})$ \\
\hline Toad rush & $0.4-0.5$ & Fathen & $1.2-1.5$ \\
Cudweed & $0.7-0.9$ & Waxweed & $1.5-1.7$ \\
Speedwell & $0.8-1.0$ & Black nightshade & $1.6-2.0$ \\
Smooth witchgrass & $0.9-1.2$ & Willow weed & $2.0-2.5$ \\
Lotus & $1.0-1.3$ & Annual poa & $2.0-3.0$ \\
Spurrey & $1.0-1.3$ & Summer grass & $2.0-3.0$ \\
\hline
\end{tabular}

Three of the weeds studied are winter growing broadleaf weeds viz. speedwell, waxweed and lotus, with medium to large size seed. Of these, wax weed and Lotus appear to be constrained by depth with seedling numbers in the $50 \mathrm{~mm}$ soil columns being no larger than those for the $30 \mathrm{~mm}$ soil columns (Fig. 1b). However, speedwell which has the smaller seed, was not constrained at depths greater than $30 \mathrm{~mm}$ and had a large increase in seedling emergence in the $50 \mathrm{~mm}$ deep soil column compared to the $30 \mathrm{~mm}$ soil column. Again, the work of Chancellor (1964) showed that few speedwell seedlings emerged from depths greater than $30 \mathrm{~mm}$ and is in contrast to results from this study.

Grass weeds showed a similar trend with the smaller seeded smooth witchgrass not constrained by depth, while the larger seeded annual poa and summer grass showed a distinct levelling off of emergence numbers from depths greater than 15 and $20 \mathrm{~mm}$ respectively (Figs 1c \& 2b). The two remaining weeds, cudweed and toad rush, have the smallest seed of the weeds presented here and appear to be constrained by depths greater than $5 \mathrm{~mm}$ and $10 \mathrm{~mm}$ respectively (Fig. 1d). 

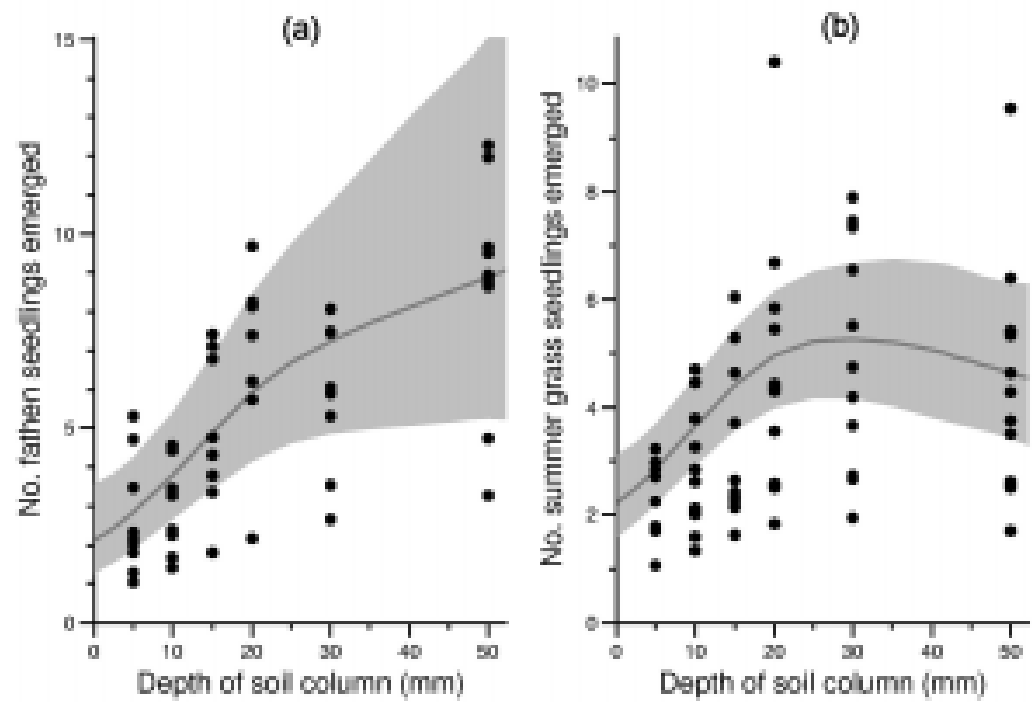

FIGURE 2: Total number of seedlings of (a) fathen and (b) summer grass emerging from soil columns of different depths. A Bayesian smoothing spline is fitted and $95 \%$ confidence intervals are shown by the shaded area. Data are the total number for individual soils.

It is generally accepted that the depth in the soil from which weed seedlings can emerge is related to seed size with smaller seeds lacking the energy reserves to emerge from greater depths. The findings of this study partly support that but also demonstrate crucial exceptions to this rule for some common arable weeds in New Zealand. Results also show that in the lighter New Zealand soils, many weed species are capable of emerging from depths of at least up to $50 \mathrm{~mm}$ but probably more. Hence, data generated in overseas experiments relating seed depth to weed emergence are not necessarily applicable to New Zealand soils. However, the data from this study using light textured volcanic soils might not readily apply to heavier silt and clay soils from other regions of New Zealand. Thus, using soil weed seedbank numbers to estimate future weed populations may require some site specific information on weed emergence.

\section{ACKNOWLEDGEMENT}

Thanks are due to Judy Mellsop for training and helping Tanya Webster with her BSc.Tech (Waikato) project.

\section{REFERENCES}

Anon. 1990: Seeds in New Zealand Agriculture. MAF Seed Testing Station, Palmerston North, N.Z. p. 52.

Buhler, D.D.; Mester, T.C. 1991: Effect of tillage systems on the emergence depth of giant (Setaria faberii) and green foxtail (Setaria viridis). Weed Sci. 39: 200-203.

Cardina, J.; Sparrow, D.H. 1996: A comparison of methods to predict weed seedling populations from the soil seedbank. Weed Sci. 44: 46-51.

Chancellor, R.J. 1964: The depth of weed seed germination in the field. Proc. $7^{\text {th }}$ Brit. Weed Control Conf. 2: 607-613. 
du Croix Sissons, M.J.; Van Acker, R.C.; Derksen, D.A.; Thomas, A.G. 2000: Depth of seedling recruitment of five weed species measured in situ in conventional- and zero-tillage fields. Weed Sci. 48:327-332.

Forcella, F. 1993: Prediction of weed densities from the soil seed reservoir. Proc. Int. Symp., Indian Soc. Weed Sci. (Hisar, India) 1: 53-56.

Grundy, A.C.; Mead, A.; Burston, S. 1999: Modelling the effect of cultivation on seed movement with application to the prediction of weed seedling emergence. J. Appl. Ecol. 36: 663-6781.

James, T.K.; Rahman, A.; Wardle, D.A.; Bonner, K.I. 1998: Survival of nodding thistle (Carduus nutans) seed buried at different depths in four soils. Proc. 51 st N.Z. Plant Prot. Conf.: 33-37.

Murdoch, A.J.; Ellis, R.H. 1992: Longevity, viability and dormancy. In: Fenner, M. ed. Seeds: The Ecology of Regeneration in Plant Communities. CAB International, Wallingford, United Kingdom. Pp. 193-229.

Wilson, B.J.; Lawson, H.M. 1992: Seedbank persistence and seedling emergence of seven weed species in autumn-sown crops following a single year's seeding. Ann. Appl. Biol. 120: 105-116. 